\title{
OVERVIEW OF THE UNATED STATES AND THE EUROPEAN UNION STANDARDS IN TERMS OF ANALYSIS OF BUILDINGS AND STRUCTURES UNDER SEISMIC WAVE ACTION
}

\author{
Yu.P. Nazarov ${ }^{1}$ E.V. Poznyak ${ }^{1,2}$ \\ ${ }^{1}$ JSC Research Center of Construction, Moscow, Russia \\ ${ }^{2}$ Moscow Power Engineering Institute National Research University, Moscow, Russia
}

\begin{abstract}
The article discusses the terms of the US and EU standards (ASCE -7-10, ASCE-4-98, FEMA P-1051/2016, EN 19986: 2005) concerning the calculations of earthquake -resistant buildings and structures taking into account wave seismic effects in the ground base. For the considered standards, wave propagation models and accepted approaches to seismic analysis were investigated; limitations on the use of the standard methods were identified.
\end{abstract}

Keywords: Seismic waves, wave model of seismic ground motion, seismic analysis, rotational seismic ground motion, linear dynamic analysis, rotational response spectra.

\section{АНАЛИЗ НОРМ США И ЕВРОСОЮЗА В ЧАСТИ РАСЧЕТОВ ЗДАНИЙ И СООРУЖЕНИЙ НА ВОЛНОВЫЕ СЕЙСМИЧЕСКИЕ ВОЗДЕЙСТВИЯ}

\author{
Ю.П. Назаров" ${ }^{1}$, Е.В. Позняк ${ }^{1,2}$ \\ ${ }^{1} \mathrm{AО}$ «НИЦ «Строительство», Москва, Россия \\ ${ }^{2}$ ФББОУ ВО НИУ «МЭИ», Москва, Россия
}

\begin{abstract}
Аннотация: В статье приведен анализ положений ряда сейсмических норм США и Евросоюза (ASCE-7-10, ASCE-4-98, FEMA P-1051/2016, EN 1998-6:2005) по проектированию сейсмостойких зданий и сооружений с учетом волновых сейсмических эффектов в грунтовом основании. Исследованы заложенные в нормы модели распространения волн и принятые подходы к проектному расчету, выявлены ограничения по применению нормативных методик.
\end{abstract}

Ключевые слова: Сейсмические волны, волновая модель сейсмического движения грунта, расчет на сейсмостойкость, ротационное сейсмическое движение грунта, линейный динамический анализ, ротационные спектры ответа.

The wave seismic effects on buildings and structures occur when seismic waves pass through the ground base. Since seismic waves velocities are finite, there is a time-delay between kinematic parameters (displacements, velocities, accelerations) at various points of the ground. For correct analysis of spatial buildings and structures, it is necessary to consider a space-time field of displacements, velocities and accelerations at points of their ground base. As presented in [1-3], the effect of seismic wave propagation is introduced into the analysis by seismic impact vector consisting of three translational and three rotational (angular) components at each point of the ground base. In particular, in [1] is discussed the conditions under which the field of ground wave motions at the base is reduced to a single seismic impact vector applied to the geometric center of the base. Ideas about the rotational components of seismic motion, which must be considered in structural analyses together with translational ones, appear in many scientific publications, see, for example, [4-7]. The need to take into account the rotational seismic motion at the base for some types of buildings and structures is present in foreign standards. This problem has been most fully resolved in the EU building codes, and to a much lesser extent - in the United States. 
Overview of the Unated States and the European Union Standards in Terms of Analysis of Buildings and Structures Under Seismic Wave Action

In the ASCE-7-10 [8], the rotational motion is simulated by random eccentricities for overlaps of structure (the corresponding explanations are given in [9]). A similar approach to accounting for wave phenomena in the engineering design is observed in the American atomic standards ASCE 4-98 ([10], C.3.3.1.2). ASCE 4-98 accepts the hypothesis about vertical propagation of body seismic waves.

The seismic analysis is performed on vertical displacements of the base from P-waves and horizontal displacements from shear waves. Apparent velocity of vertical shear waves on the surface tends to infinity and there are no rotations. The simplified model of seismic motions as vertically propagating body waves should be used with the simultaneous setting of overlap's random eccentricities, for guarantee that the building or structure will not be affected by any unaccounted wave effects. Further in C.3.3.1.2, it is noted the complexity of the real wave motions in the base and the corresponding features of the dynamic behavior of structures, such as associated horizontal, vertical, torsional and rocking motions, depending on the soil parameters, the foundation, the frequency range, etc.

Consider in detail the approach implemented in the European seismic standards EN 1998-6: 2005 [11]. In EN 1998-6:2005, spatial translational and rotational ground motions should be taken into account for tall structures (towers, masts, chimneys, etc.). In 3.1 "Definition of the seismic input" EN 1998-6:2005 it is written: "In addition to the translational components of the earthquake motion, defined in EN 1998$1: 2004,3.2 .2$ and 3.2.3, the rotational component of the ground motion should be taken into account for tall structures in regions of high seismicity." A Note 1 to p.3.1 states that conditions under which the rotational component of the ground motion should be taken into account in a country, will be found in National Annex. The recommended conditions are structures taller than $80 \mathrm{~m}$ in regions where the product $a_{g} S$ exceeds $0.25 g$, where $a_{g}$ is the design ground acceleration for type $A$ ground; $S$ is the soil factor; $a_{g} S$ - design acceleration of soil for a given soil. Informative Annex gives a possible method to define the rotational components of the ground motion and provides guidance for taking them into account in the analysis. It should be noted that the National Annexes of the EU countries (for example,
Cyprus, Greece) use Appendix A in its original form without changes [13-14]. An analysis according to the informative Annex A of EN 1998-6: 2005 "Linear dynamic analysis accounting for the rotational components of the ground motion" should be carried out if there are no results of a special study or welldocumented field measurements. In these cases, the rotational response spectra may be determined as:

$$
\begin{aligned}
& R_{x}^{\theta}(T)=1,7 \pi S_{e}(T) / v_{s} T, \\
& R_{y}^{\theta}(T)=1,7 \pi S_{e}(T) / v_{s} T, \\
& R_{z}^{\theta}(T)=2,0 \pi S_{e}(T) / v_{s} T,
\end{aligned}
$$

where $R_{x}^{\theta}(T), R_{y}^{\theta}(T), R_{z}^{\theta}(T)$ are the rotation response spectra around $x, y$ and $z$ axes, $\mathrm{rad} / \mathrm{s}^{2} ; S_{e}(T)$ is the elastic response spectra for the horizontal components on the site, $\mathrm{m} / \mathrm{s}^{2} ; T$ is the period, $\mathrm{s} ; v_{s}$ is the average $\mathrm{S}$-wave velocity of the top $30 \mathrm{~m}$ of the ground profile, $\mathrm{m} / \mathrm{s}$.

The velocity $v_{s}$ is directly evaluated by field measurements, or through the laboratory measurement of the shear modulus $G$ and the soil density $\rho$ as $v_{s}=\sqrt{ } G / \rho$, or $v_{s}$ is accepted for standard ground type A, B, C and $\mathrm{D}$ equal to $800,580,270$ and $150 \mathrm{~m} / \mathrm{s}$, respectively. Rotational response spectra have the same physical meaning as response spectra for translational motion, but in terms of angular accelerations: this is the maximum angular acceleration of an oscillator with natural period $T$ and $a$ damping coefficient $\xi$ in response to ground rotations with peak angular acceleration $\ddot{\theta}$. The analysis is performed simultaneously for three translational and three rotational components of the seismic ground motions.

Appendix A shows the equations of motion for a flat cantilever model (Fig.1), which is described by horizontal translational displacements $u_{t}$ of the concentrated masses $m_{t}$ relative to the base. The seismic action is determined as translational horizontal $\ddot{X}$ and rotational $\ddot{\theta}$ ground motions with the corresponding spectra $S_{e}(T)$ and $R^{\theta}(T)$. In EN 1998-6:2005, the equations of motion are written as:

$$
[M]\{\ddot{u}\}+[C]\{\dot{u}\}+[K]\{u\}=-(\{m\} \ddot{X}+\{m h\} \ddot{\theta}),
$$

where $[M]=\operatorname{diag}\left[m_{i}\right]$ is diagonal inertia matrix, $[K]$ is the stiffness matrix, $[C]$ is the damping - matrix, $\{m\}$ is vector comprising masses $m,\{m h\}$ is vector comprising products (Fig.1). 


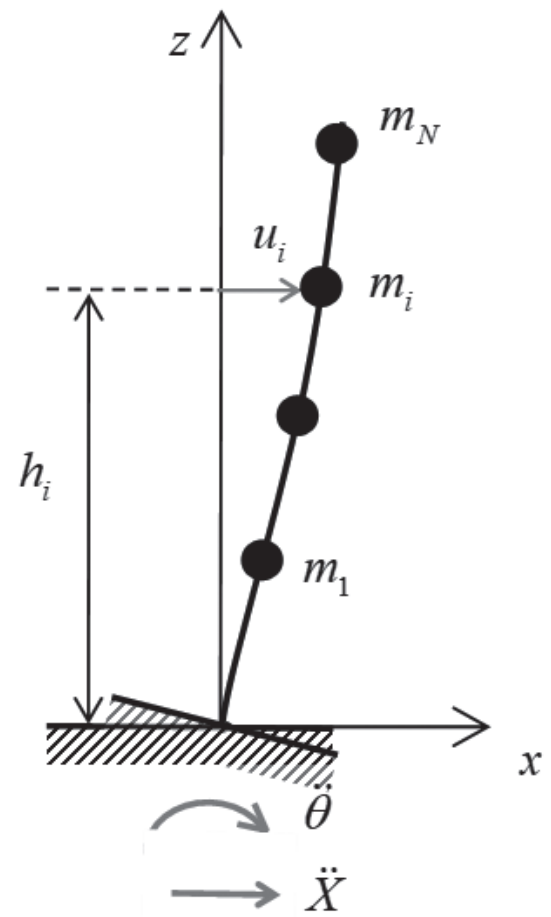

Figure 1. The flat cantilever mode

The forces on the right part of (4) are represented as two independent loads. The participation factors are determined for each load. For modal analysis, the participation coefficients of mode $\mathrm{k}$ are equal, respectively for the first and second loads in the right part (4):

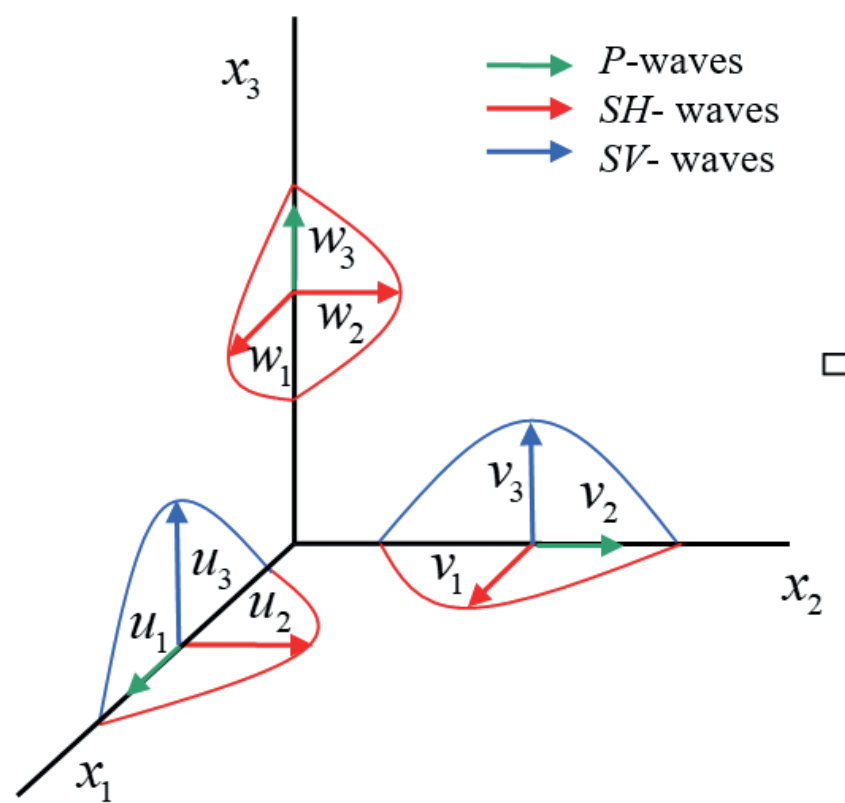

$$
a_{k u}=\frac{\left\{\Phi^{T}\right\}\{m\}}{\left\{\Phi^{T}\right\}[M]\{\Phi\}}, a_{k \theta}=\frac{\left\{(\Phi h)^{T}\right\}\{m\}}{\left\{\Phi^{T}\right\}[M]\{\Phi\}},
$$

where $\{\Phi\}$ is the k-th modal vector; $\{\Phi h\}$ is the vector of the products of the modal amplitude $\Phi$ at the i-th degree of freedom and its elevation $h_{i}$.

For linear systems in the time domain, full dynamic response to both loads is calculated as superposition of responses for each load. For linear response spectrum method, the resulting dynamic response are found by the rule SRSS (Square Root of the Sum of Squares).

We try to determine the generalized wave model $[1-3,15]$ corresponding the spectra (1)-(3). In the generalized wave model, it is assumed that translational motion $X_{i}$ along the $\mathrm{i}$-th axis is caused by shear displacements from SH- and SV-waves and longitudinal displacements from P-waves (Fig. 2):

$$
\begin{gathered}
X_{1}=u_{1}+v_{1}+w_{1}, X_{2}=u_{2}+v_{2}+w_{2}, \\
X_{3}=u_{3}+v_{3}+w_{3} .
\end{gathered}
$$

Without longitudinal displacements from P-waves which do not cause rotations:

$$
X_{1}=v_{1}+w_{1}, X_{2}=u_{2}+w_{2}, X_{3}=u_{3}+v_{3} .
$$

Further, we assume that all components of the wave motion in (5) are harmonic waves from the Fourier spectrum with the same frequency, wave number, and their own phase delay:

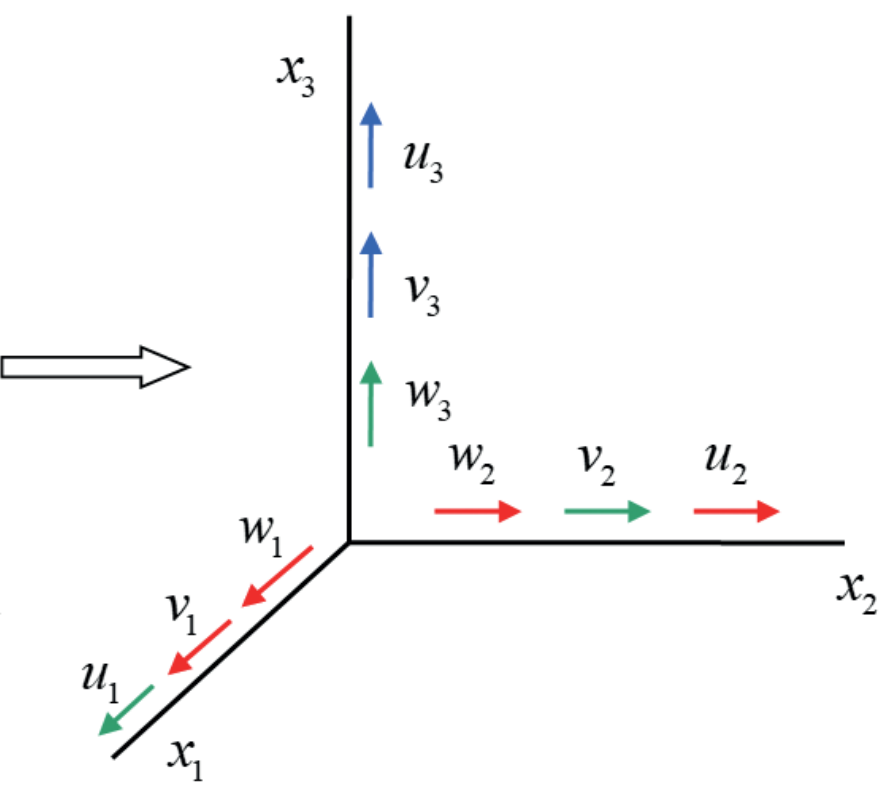

Figure 2. The generalized wave model 


$$
\begin{aligned}
& X_{1}=v_{1}+w_{1}= \\
& =A_{11} \cos \left(k x_{2}+\omega t+\varphi_{11}\right)+A_{12} \cos \left(k x_{3}+\omega t+\varphi_{12}\right), \\
& X_{2}=u_{2}+w_{2}= \\
& =A_{21} \cos \left(k x_{1}+\omega t+\varphi_{21}\right)+A_{22} \cos \left(k x_{3}+\omega t+\varphi_{22}\right), \\
& X_{3}=u_{3}+v_{3}= \\
& =A_{31} \cos \left(k x_{1}+\omega t+\varphi_{31}\right)+A_{32} \cos \left(k x_{2}+\omega t+\varphi_{32}\right) .
\end{aligned}
$$

Accelerations of the translational motion are equal:

$$
\begin{aligned}
& \ddot{X}_{1}=-\omega^{2} A_{11} \cos \left(k x_{2}+\omega t+\varphi_{11}\right)- \\
& -\omega^{2} A_{12} \cos \left(k x_{3}+\omega t+\varphi_{12}\right), \\
& \ddot{X}_{2}=-\omega^{2} A_{21} \cos \left(k x_{1}+\omega t+\varphi_{21}\right)- \\
& -\omega^{2} A_{22} \cos \left(k x_{3}+\omega t+\varphi_{22}\right), \\
& \ddot{X}_{3}=-\omega^{2} A_{31} \cos \left(k x_{1}+\omega t+\varphi_{31}\right)- \\
& -\omega^{2} A_{32} \cos \left(k x_{2}+\omega t+\varphi_{32}\right)
\end{aligned}
$$

with maximum absolute values:

$$
\begin{aligned}
& \max \left|\ddot{X}_{1}\right|=\omega^{2}\left(A_{11}+A_{12}\right), \\
& \max \left|\ddot{X}_{2}\right|=\omega^{2}\left(A_{21}+A_{22}\right), \\
& \max \left|\ddot{X}_{3}\right|=\omega^{2}\left(A_{31}+A_{32}\right) .
\end{aligned}
$$

Rotational accelerations are calculated using wellknown formulas (see, for example, in $[1,2])$ :

$$
\begin{aligned}
& \ddot{\theta}_{1}=\frac{1}{2}\left(\frac{\partial \ddot{X}_{3}}{\partial x_{2}}-\frac{\partial \ddot{X}_{2}}{\partial x_{3}}\right)= \\
& =\omega^{2} \frac{k}{2}\left(A_{32} \sin \left(k x_{2}+\omega t+\varphi_{32}\right)-\right. \\
& \left.-A_{22} \sin \left(k x_{3}+\omega t+\varphi_{22}\right)\right), \\
& \ddot{\theta}_{2}=\frac{1}{2}\left(\frac{\partial \ddot{X}_{1}}{\partial x_{3}}-\frac{\partial \ddot{X}_{3}}{\partial x_{1}}\right)= \\
& =\omega^{2} \frac{k}{2}\left(A_{12} \sin \left(k x_{3}+\omega t+\varphi_{12}\right)-,\right. \\
& \left.-A_{31} \sin \left(k x_{1}+\omega t+\varphi_{31}\right)\right), \\
& \ddot{\theta}_{3}=\frac{1}{2}\left(\frac{\partial \ddot{X}_{2}}{\partial x_{1}}-\frac{\partial \ddot{X}_{1}}{\partial x_{2}}\right)= \\
& =\omega^{2} \frac{k}{2}\left(A_{21} \sin \left(k x_{1}+\omega t+\varphi_{21}\right),\right. \\
& \left.-A_{11} \sin \left(k x_{2}+\omega t+\varphi_{11}\right)\right) .
\end{aligned}
$$

The maximum absolute values of rotational accelerations are equal to

$$
\begin{aligned}
& \max \left|\ddot{\theta}_{1}\right|=\omega^{2} \frac{k}{2}\left(A_{32}+A_{22}\right), \\
& \max \left|\ddot{\theta}_{2}\right|=\omega^{2} \frac{k}{2}\left(A_{12}+A_{31}\right), \\
& \max \left|\ddot{\theta}_{3}\right|=\omega^{2} \frac{k}{2}\left(A_{21}+A_{11}\right) .
\end{aligned}
$$

Rotational spectra (1)-(3) are expressed only in terms of acceleration of horizontal translational motion, so $\ddot{X}_{3}=0$ and $A_{31}=A_{32}=0$, therefore

$$
\begin{aligned}
& \max \left|\ddot{X}_{1}\right|=\omega^{2}\left(A_{11}+A_{12}\right) \\
& \max \left|\ddot{X}_{2}\right|=\omega^{2}\left(A_{21}+A_{22}\right), \\
& \max \left|\ddot{\theta}_{1}\right|=\omega^{2} \frac{k}{2} A_{22}, \max \left|\ddot{\theta}_{2}\right|=\omega^{2} \frac{k}{2} A_{12}, \\
& \max \left|\ddot{\theta}_{3}\right|=\omega^{2} \frac{k}{2}\left(A_{21}+A_{11}\right) .
\end{aligned}
$$

Assuming that the amplitudes in the above formulas are of the same order, we estimate translational and rotational accelerations

$$
\frac{\max \left|\ddot{\theta}_{i}\right|}{\max \left|\ddot{X}_{i}\right|} \sim k .
$$

The estimation (8) shows the ratio of the maximum amplitudes of the rotational and translational components of the seismic impact. For the linear system, the estimation (8) is also true for the translational and rotational response spectra. The wave number $k$ is related to the wavelength $\lambda=v_{s} T$, and, accordingly, to its period $T$ and phase velocity $v_{s}$ :

$$
k=\frac{2 \pi}{\lambda}=\frac{2 \pi}{v_{s} T} .
$$

The spectra (1)-(3) with accounting (8) and (9):

$$
\begin{aligned}
& R_{x}^{\theta}(T)=0,85 \frac{2 \pi}{v_{s} T} S_{e}(T), \\
& R_{y}^{\theta}(T)=0,85 \frac{2 \pi}{v_{s} T} S_{e}(T), \\
& R_{z}^{\theta}(T)=\frac{2 \pi}{v_{s} T} S_{e}(T) .
\end{aligned}
$$

Consider in (10) the Type 1 elastic response spectra for horizontal translational motion $S_{e}(T)$ determined in Table $1[11,12]$. 
Table 1. Type 1 Elastic response spectra

\begin{tabular}{|c|c|}
\hline Period & Response spectra \\
\hline $0<T \leq T_{B}$ & $S_{e}(T)=a_{g} S\left[1+\frac{T}{T_{B}}(2,5 \eta-1)\right]$ \\
\hline$T_{B} \leq T \leq T_{C}$ & $S_{e}(T)=a_{g} S \eta \cdot 2,5$ \\
\hline$T_{C} \leq T \leq T_{D}$ & $S_{e}(T)=a_{g} S \eta \cdot 2,5\left[\frac{T_{C}}{T}\right]$ \\
\hline$T_{D} \leq T \leq 4 \mathrm{c}$ & $S_{e}(T)=a_{g} S \eta \cdot 2,5\left[\frac{T_{C} T_{D}}{T^{2}}\right]$ \\
\hline
\end{tabular}

Fig. 3 and 4 show graphs of the rotational response spectra (10) and translational response spectra given in Table.1. The translational spectra are shown as a solid line, the rotational spectra as a dotted line. Fig. 3 is drawn for soil A with $V_{s}=800 \mathrm{~m} / \mathrm{s}$, Fig. $4-$ for soil $D$ with $V_{s}=150 \mathrm{~m} / \mathrm{s}$.

The graphs of the rotational spectra in Fig. 3 and 4 show that the rotational motion corresponding to (1)-(3) is a high-frequency component of the seismic action, the contribution of which to the structural response increases for soft, loose soils. The reduction coefficients in (1)-(3) equal to 0.85 for rotational spectra with respect to two horizontal axes. It seems to have been introduced artificially (for example, to account for the non-synphase of seismic waves or the weakening of the dynamic response due to the scattering of seismic waves).

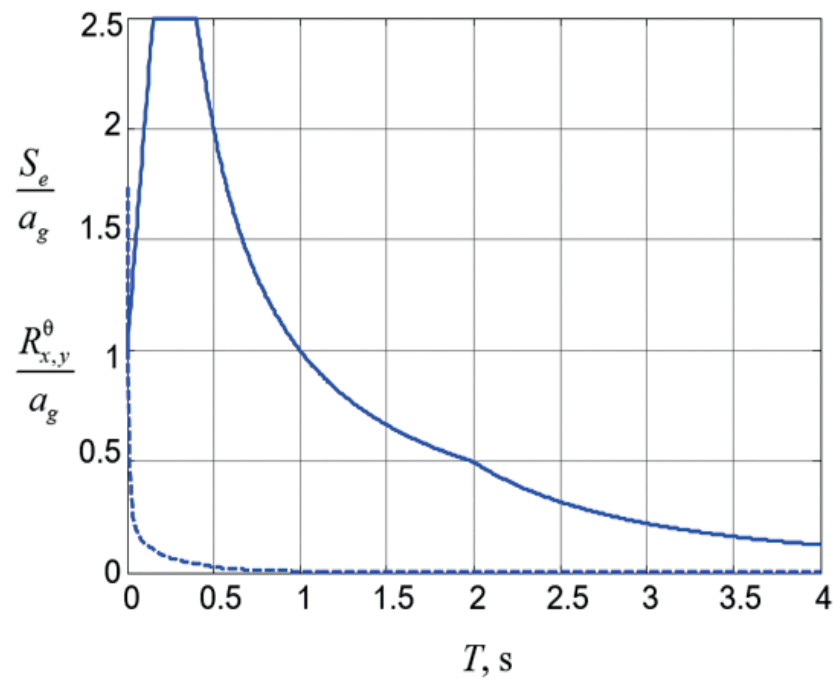

Figure 3. Translational and rotational response spectra. Ground A, Type I

\section{CONCLUSIONS}

1. The US standards ASCE-7-10 and ASCE4-98 accepted a model of vertical body wave propagation. In this case, the horizontal and vertical displacements of the base are caused by shear waves and compression waves respectively; there are no rotational components since the apparent velocity of vertical shear waves tends to infinity. The accidental eccentricity is used to indirectly account for various effects, including: plan distributions of mass that differ from those assumed in design, variations in the mechanical properties of structural components, nonuniform yielding of the lateral system, and torsional and rotational ground motions [9]. However, the accidental eccentricity approach cannot be called successful for simulating torsional and rotational ground motions, since the motion of a dynamical system with eccentricities and with ground rotations has different causes and is described by different equations. Simple illustrative examples of the equations of motion can be found in [16].

2. In the European Union standard EN 1998-6:2005 it is proposed a method of analysis of tall structures (towers, masts, chimneys, etc.) for simple flat cantilever (Fig.1) with the equation of motion (4). Rotational response spectra (1)-(3) are expressed through the response spectra of horizontal translational motion. The method is based on a simplified wave model as a composition of $\mathrm{SH}$-waves propagating

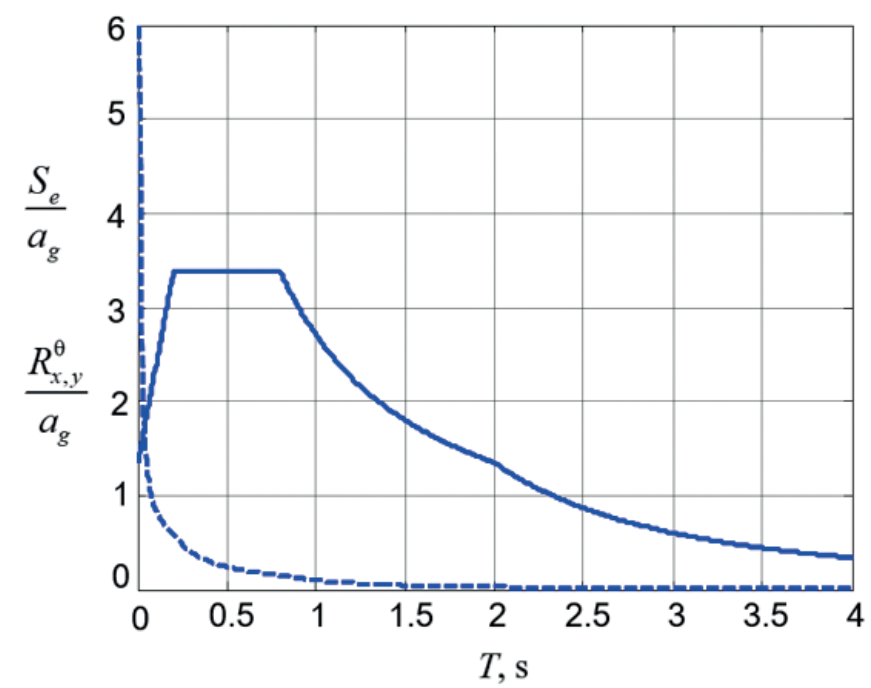

Figure 4. Translational and rotational response spectra. Ground D, Type I 
Overview of the Unated States and the European Union Standards in Terms of Analysis of Buildings and Structures Under Seismic Wave Action

in two orthogonal horizontal directions with a finite phase velocity. For this wave model, the rotational response spectra are obtained, and the rules for calculating the resulting forces under the combined action of translational and rotational components of seismic motion are described. The spatial extended and large-span buildings and structures are not considered in the Eurocode. The reason is probably in a lack of scientific and methodological basis.

\section{REFERENCES}

1. Nazarov Y.P. Analiticheskie osnovy rascheta sooruzheniy na seysmicheskie vozdeystviya [The analytical calculation fundamentals of constructions on seismic loads]. - M.: Nauka, 2010; 414. (RUSSIAN)

2. Nazarov Y.P. Raschetnye modeli seysmicheskikh vozdeystviy [Models of seismic actions for calculation].-M.: Nauka, 2012; 468. (RUSSIAN)

3. Yuri P. Nazarov, Elena Poznyak, Anton V. Filimonov. A brief theory and computing of seismic ground rotations for structural analyses. Soil Dynamics and Earthquake Engineering, 71 (2015), Pages 31-41.

4. Lee W.H.K., Kanamori H., Jennings P., Kisslinger C. / International Handbook of Earthquake \& Engineering Seismology, Part B. Academic Press, 2003.

5. Bońkowski P.A., Zembaty Z., Minch M.Y. Time history response analysis of a slender tower under translational-rocking seismic excitations. Engineering Structures 155. (2018). 387-393.

6. D. Basu, A.S. Whittaker, M.C. Constantinou. Characterizing rotational components of earthquake ground motion using a surface distribution method and response of sample structures. .Engineering Structures 99 (2015) 685-707

7. F. Vicencio, N.A. Alexander. A parametric study on the effect of rotational ground motions on building structural responses, Soil Dynamics and Earthquake Engineering, Volume 118, 2019, Pages 191-206.

8. ASCE/SEI 7-10 Minimum design loads for buildings and other structures.

9. FEMA P-1051/2016 NEHRP Recommended Seismic Provisions: Design Examples.

10. ASCE 4-16 Seismic Analysis of Safety-Related Nuclear Structures and Commentary

11. EN 1998-6:2005 Eurocode 8: Design of structures for earthquake resistance - Part 6: Toers, masts and chimneys

12. EN 1998-1:2005 Eurocode 8: Design of structures for earthquake resistance - Part 1: General rules, seismic actions and rules for buildings.

13. CYS EN 1998-6:2005 Eurocode 8: Design of structures for earthquake resistance. Part 6: Towers, masts and chimneys

14. BS EN 1998-6:2005 UK National Annex to Eurocode 8. Design of structures for earthquake resistance. Towers, masts and chimneys

15. Yu.P. Nazarov, E.V. Poznyak. Estimate of Rotational Components of Seismic Ground Motion//Soil Mechanics and Foundation Engineering, 2016, Volume 52, Issue 6, pp 355-360.

16. E.V. Poznyak. Osnovy teorii seismostoykosti stroitel'nykh konstrukziy. [Fundamentals of the earthquake resistance theory of building structures]. - M.: Izdatel'stvo MEI. 2016.

Yuri P. Nazarov, doctor of technical Sciences, head of the sector "Earthquake resistance of structures" of JSC Research Center of Construction. 109428, Moscow, 2nd Institutskaya str., 6, building 1. Email: nazarov-dom@mail.ru. Tel.: +7 (495) 602-00-70

Назаров Юрий Павлович, д.т.н., заведующий сектором «Сейсмостойкость сооружений» АО «НИЦ «Строительство». 109428, г. Москва, 2-я Институтская ул., д.6, корпус 1. Email: nazarov-dom@mail.ru. Tel.: +7 (495) 602-00-70. Fax: +7 (499) 171-22-50.

Elena V. Poznyak, Ph. D., associate Professor of the Department of robotics, mechatronics, dynamics and strength of machines Moscow Power Engineering Institute National Research University, Moscow, 14 Krasnokazarmennaya street, Moscow, 111250, Russia. Tel.: +7 495 362-77-00 